\title{
Transthoracic echocardiography: adiposity, epicardial adipose tissue and right heart
}

\author{
Kristina Selthofer-Relatić, Ivica Bošnjak, Vedrana Vizjak, Robert Steiner \\ University Hospital Center Osijek, Osijek, Croatia
}

Obesity is an increasing world health problem where visceral adposity is recognized as a risk factor for the development of cardiometabolic diseases. Obesity by sistemic and local effect affect cardiac function: obesity related hypertension and hypertensive heart disease, adipokines related prohypertrophic effect, cardiac steatosis, myocardial matrix remodeling and cardiac fibrosis, epicardial autocrine/paracrine and mechanical effect. Epicardial adipose mass reflect intraabdominal visceral fat and it could serve as a reliable marker of visceral adiposity.

Effect of systemic and local, epicardial excess weight on right ventricular characteristics and function is less known. Obese persons have dyspnea as one of the first symptom in every day physical activity. In a normal heart, the right ventricle (RV) usually ejects against a low impedance circulation and the thin wall of the RV is sensitive to alterations. With chronic increase in pressure or volume overload, the RV dilatates and develops muscular hypertrophy which affect the cardiac output. RV dysfunction may affect left ventricular function, not only by limiting LV preload, but also by adverse systolic and diastolic interaction via the intraventricular septum and the pericardium. Some echocardiograhic studies showed that obese and overweight subjects have right ventricle dilatation with subclinical right ventricle dysfunction. Echocardiographic assessment of epicardial fat could be a simple and practical tool for cardiovascular risk stratification in clinical practice and research.

The purpose of this prospective study was to investigate influence of systemic adiposity and epicardial adipose tissue on the right heart anatomy and function in younger adult overweight/obese healthy/hypertensive persons without other cardiovascular diseases.

KEYWORDS: echocardiography, epicardial adipose tissue, obesity, right heart function.

\footnotetext{
Received: $20^{\text {th }}$ Mar 2013

*Address for correspondence: Klinički bolnički centar Osijek, J. Hutlera 4, HR-31000 Osijek, Croatia.

Phone: +385-31-511-511

E-mail: selthofer.relatic@gmail.com
}

\section{Literature}

1. Rudski GL, Lai WW, Afilalo J, Hua L, Handschumacher MD, Chandrasekaran K, et al. Guidelines for the echocardiographic assessment of the right heart in adults: a report from the American Society of Echocardiography. J Am Soc Echocardiogr. 2010;23:685-713.

2. Wong CY, O'Moore-Sullivan T, Leano R, Hukins C, Jenkins C, Marwick TH. Association of subclinical right ventricular dysfunction with obesity. J Am Coll Cardiol. 2006; 47(3):6116.

3. lacobellis G, Assael F, Ribaudo MC, Zappaterreno A, Alessi G, Di Mario U, et al. Epicardial fat from echocardiography: a new metod for visceral adipose tissue prediction. Obes Res. 2003;11(2):303-10.

4. Lindquist $P$, Calcutteea A, Heinein M. Echocardiography in the assessment of right heart function. Eur J Echocardiogr. 2008;9:225-234.

5. Bleeker GB, Steendjik P, Holman ER, Yu C-M, Breithardt OA, Kaandorp TAM, et al. Assessing right ventricular function: the role of echocardiography and complementary technologies. Heart. 2006;92(Suppl 1):i19-i26. 